\title{
Public Housing in Medan during the Dutch Colonial Period
}

\author{
Suprayitno $^{1}$, Wara Sinuhaji ${ }^{2}$, Deo Widika Alamsyah ${ }^{3}$ \\ ${ }^{1,2,3}$ Department of History, Faculty of Cultural Science, Universitas Sumatera Utara, Indonesia \\ suprayitno@usu.ac.id
}

\begin{abstract}
As the center of government and economy in the East Sumatra region during the Dutch colonial era, the city of Medan continued to develop and grow in line with the success of the surrounding plantation businesses. This situation resulted in many people coming to Medan to stay and settle down. The large number of people who came to Medan resulted in an increase in population in Medan which resulted in an increase in the number of housing needs at that time, especially houses that met health and safety standards. Since there were many houses that did not meet the standards at that time, the Medan City Government considered that this housing problem had to be taken seriously so they made a policy to establish public housing that met the standards set, which was called "Volkshuisvesting" or people's houses. This housing development policy was also widely carried out in several Gemeente in the Dutch East Indies at that time. Volkshuisvesting itself is public housing aimed at middle and low income people with the aim of helping them to have a decent place to live in. Many things have been prepared by the Medan City government to realize this public housing policy for the people or Volkshuisvesting, starting from planning, provision of funds, housing areas etc. Using historical methods and using sources such as the Dutch colonial archives, newspapers and books that discuss housing published during the Dutch colonial period, this article explains how the Medan City Government plans to build public housing in Medan.
\end{abstract}

Keywords

public housing, Medan;

Volkshuisvesting

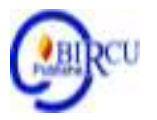

\section{Introduction}

Home has always been an important human need in every age and every place. The growth in the number of people always demands and has an impact on the ever-increasing needs of houses, both in quantity and quality. The need for this home sometimes becomes a serious problem and must be handled properly because it covers the lives of many people. Many governments in an area have to make regulations or policies to be able to regulate how people build their houses and not infrequently the government itself has to help by providing houses for the people.

The city of Medan at the beginning of the 20th century was an urban area that developed quite rapidly as the center of government for the residency of East Sumatra and was surrounded by plantation businesses. It turns out that the development of Medan has become the main attraction for many people, resulting in a wave of migration to this area 
Konfrontasi Journal: Culture, Economy and Social Changes, 7 (3) September 2020, 217-227

ISSN: 1410-881X (Print), 2716-2095 (Online)

\section{Suprayitno, Wara Sinuhaji, Deo Widika Alamsyah: Public Housing in Medan during the Dutch Colonial Period}

DOI: https://doi.org/10.33258/konfrontasi2.v7i3.117

http://www.konfrontasi.net/index.php/konfrontasi2

and resulting in a significant growth of the population consisting of various races. ${ }^{1}$

Due to the increasing population growth, this certainly has an impact on the increasing need for housing, in this case it is emphasized that the house in question is a house that meets standards and is livable. Because the village areas in Medan are still found houses in conditions that do not meet the standards with dirty and messy conditions. ${ }^{2}$ As a result of this problem, the City Government (Gemeente) of Medan took the initiative that new housing developments were needed, especially housing that could be reached by the middle to poor economic groups. ${ }^{3}$ Therefore this article will explain how the efforts of the Medan City Government during the colonial period to build public housing for the people in order to overcome the slum face of Medan City housing.

\section{Review of Literature}

\subsection{Housing Problems in Medan}

a. Economic Problems and Population Growth

Housing in Medan during the Dutch East Indies era, to be precise in the early 20th century, had many problems, especially houses that were unfit for habitation with dirty and dirty conditions. This is often found in several areas, especially the villages in Medan. ${ }^{4}$ This situation is not without cause. Due to the low economic capacity of the community, building a good house was a problem at that time, especially for indigenous people and migrants such as contract coolies, because again the problem of building a good house was based on economic capacity. For contract coolies in Deli, based on the terms of the applied work contract, from 1910 to 1912 the wages for native coolies were only around 0.29 to 0.46 guilders per day. ${ }^{5}$ It can be estimated that for a month they can produce 8.7 to 13.8 guilders, of course, provided that they have to work a full 30 working days without any holidays. With such economic conditions, it can be said that they are far from their ideal needs. When compared with the price of goods at that time, let's say one sarong which costs 1 dollar, they even took a few days to buy it. ${ }^{6}$ From this situation we can conclude why many slum houses do not meet the standards of standing on the outskirts of Medan such as in villages.

Although it cannot be said that most of the people with low economies come from these contract coolies, we can predict that they are the one who contributes to the poor condition of housing in Medan. Whereas this contract laborer or former contract laborer was one of the factors that caused the increase in the population in Medan and the Deli area at that time. It was recorded that up to $1907,82,500$ coolies had been brought to Deli where Medan was also located. ${ }^{7}$ Even though it is known that the contract coolies who are brought in initially will be given a place to live, but not forever they can remain there. When their tenure ends they must

\footnotetext{
${ }^{1}$ Junaidi Nasution, Transformasi Moderenitas di Kota Medan : Dari Kampung Medan Putri Hingga Gemeente Medan, Jurnal Masyarakat Sejarawan Indonesia,2018, p 66

${ }^{2}$ H.F Tillema, Zonder Tropen-geen Europam, Bloemendal, 1926, p 17

${ }^{3}$ Freek Colombijn, Public Housing in Post-Colonial Indonesia The Revolution Of Rising Expectations, Bijdragen Tot de Taal- Land- en Volkenkunde/ Juornal Of Humanities and Sosial Sciences Of Southeast Asia and Oceania, 2011, P 439

${ }^{4}$ Tillema., Loc., cit

${ }^{5}$ Koloniale verslag 1915

${ }^{6}$ Mohammad Said, Koeli Kontrak Tempoe Doeloe. Dengan Derita dan Kemarahannya, Medan, Waspada, 1977, p 87

${ }^{7}$ J.S.C Kastelijn, Deli Planters Vereeniging. Handelingen Van Het Ie Congres 1911. Het verkrijgen van een inheemsche Aïteiders-bevolking, Medan,TYP J Halerman, 1911, p 58
} 
leave. While working they are usually placed in barracks and they are often found in dirty and stuffy conditions. ${ }^{8}$

The urban structure like this was very identical with the other traditional Melayu monarchies in Sumatera. This system was established because there was the authority in the strategic area or downstream which was crowded for commercial activities. Merchants from the upstream who wanted to sell their agricultural and forest products would be charged with excise tax. The same was true to the merchants who came from the other islands (foreland) and wanted to purchase the commodities; they would be charged with excise tax, too. From these taxes, the authority was established which would eventually establish Melayu traditional monarch. (Suprayitbo, 2020)

\section{b. Soil and Slum Houses}

The question that arises from the conditions previously described is where they have to live if they are no longer working as coolies on plantations that can provide them with a place to live. This is even more so if they are married and do not want or cannot return to where they came from. Perhaps the only way they could do was to build their own house according to their abilities. This is indeed possible, since Deli Maatschippij is indeed a large plantation company in the Deli area, also giving away the land they own for free and also leasing it for 5 to 10 cents per meter for housing needs with the hope of Medan's development. ${ }^{9}$ On the other hand, the handover of land by the Government (Resident of East Sumatra) with the aim of housing has been carried out since 1887 where Medan has been designated as the Resident Capital of East Sumatra. ${ }^{10}$ This policy can also be seen as the reason why there are many dirty and slum houses on the outskirts of Medan, especially in the villages. The ease of obtaining land helps anyone to get land for their home, especially people with low economies. Land grants or grants, known as grants, which were implemented in 1889, were indeed distributed at that time and this policy also had an impact on increasing the amount of land for houses in Medan. It should be noted that there are 3 types of grants in Deli, namely Controleurgrants, Deli Maatschappijgrants and Sultangrants. ${ }^{11}$

Table 1. Distributed Grant

\begin{tabular}{|l|l|}
\hline Grant type & Total shared \\
\hline Controleursgrants & 1909 \\
\hline Deli Maatschapijjgrants & 817 \\
\hline Sultangrants & 863 \\
\hline Total & $\mathbf{3 5 8 9}$ \\
\hline
\end{tabular}

Source: De Zorg Voor DE Vokshuisvesting In De Stadgemeenten . N Nederlandsch Oost Indie In Het Bijzonder In Semarang, Grevenhage Martinus Nijhoff., 1930, p 215

By referring to the names of the villages in Medan at that time such as Djati hulu, Rengas, aur, etc., Tillema stated a significant difference between the situation in the center of Medan and the village areas such as heaven and hell. The squalid conditions that do not meet

\footnotetext{
${ }^{8}$ Tideman, Penampungan Kuli Kontrak di Panatai Timur Sumatera, colonial student 1919, p 129

${ }^{9}$ Gerad Jansen, Grantrechten In Deli, Medan, , Oostkust Van Sumatra Instituut, 1925, p 43

${ }^{10}$ Ibid., p 9

${ }^{11}$ G. Flieringa, De Zorg Voor DE Vokshuisvesting In De Stadgemeenten . N Nederlandsch Oost Indie In Het Bijzonder In Semarang
} 
the requirements for good drinking are evident. ${ }^{12}$ Another evidence obtained about poor housing in Medan was an investigation conducted by the Medan City Work Agency from 1918 to 1923 which found a strong fact that there was a large shortage of houses in Medan City based on this inspection. Even some houses in the city are very crowded and are considered to be the source of a dangerous plague. In many cases the entry of light and air and disposal of waste such as feces is not sufficient. In short, this examination found the fact that Medan was in serious trouble and had to be quickly addressed. ${ }^{13}$

Actually the Medan City government itself has a standard regulation on how to build a good building and is called the Medansche Bouwverordening. This regulation itself concerns several matters, namely building supervision, construction, housing supervision including provisions and sanctions. This regulation itself is considered ineffective, so there is an opinion whether there should be an update on the regulation. ${ }^{14}$ Indeed, from 1912 to 1924 , 520 houses and 292 other buildings were rejected and demolished. ${ }^{15}$ If this regulation is only intended to be a standard and reference for how people can build their houses, of course this is not the expected solution, because it is known that people with bad houses are people who are economically disadvantaged. With such conditions, of course what is expected and needed is direct assistance by providing good and proper houses from the City Government itself.

\section{Discussion}

\subsection{Housing Improvement Policies and Efforts in Medan}

\section{a. Planning and funding}

Policies and steps taken by the Medan City government to deal with this housing problem are planning public housing (Volkshuisvesting), namely public housing aimed at the people, especially those with low economies. A public housing commission was formed to deal with this problem. The commission, which was formed in 1919, consists of 4 members, namely H. A. Wakker as chairman and Dr. H. Vervoort, A. P. Varekamp, Mohamad Noech as members. However, in 1922 the public housing commission was merged with the land affairs commission. ${ }^{16}$

H.A Wakker as chairman of this commission, voiced about the need to handle housing which is getting worse day by day. However, it seems that the City Government is not that aware. Fortunately, in 1920, the issue of house fires made the Medan City Government aware of being involved and dealing with this abnormal condition of housing in Medan. ${ }^{17}$ On 21 July 1920 a proposal was submitted in a city council meeting. With pleasure and unanimity, this proposal can be approved. The visible result of the proposal submitted by the public housing commission is a fund of 45,000 guilders for the initial phase of the realization of Volkshuisvesting or public housing. ${ }^{18}$ From this fund, several model houses were built in Kampong Sekip.

\footnotetext{
12 Tillema, loc., cit.

${ }^{13}$ Volkshuisvesting te Medan, 1925

${ }^{14}$ De Sumatra Post, 28 Oktober 1924

${ }^{15}$ De volkshuisvesting Te Medan, 1925

${ }^{16}$ Verslag Betreffende De Gemeente Medan Over Het Jaar 1919, Medan, Varekamp \& Co, 1920 , p 16

${ }^{17}$ De volkshuisvesting te Medan, 1925

${ }^{18}$ Verslag Betreffende De Gemeente Medan Over Het Jaar 1920, Medan, Varekamp \& Co, 1921, p 58
} 
To continue this housing development, Medan City needs a large amount of money. At this stage the City of Medan is experiencing difficulties because their finances cannot cover the required costs. This problem of money difficulties also made Medan City failing to take over N.v Waterleiding Maatschappij "Ajer Beresih" because in 1919 the revenue and expenditure budget of Medan City was only 510,464 guilders, which made them have to find loans even though they failed to get it. ${ }^{19}$ Similar but slightly different, this time Medan had to find a loan to be able to continue the housing development they had planned. But a letter of advisor to decentralization dated February 28, 1921 No. 287 / V stated that Medan no longer needed to ask for financial assistance from the government (Dutch East Indies) and was advised to seek loans. The first attempt he made was to try to borrow money from Postpaarbank. This first attempt failed due to the difficult requirements filed by Pospaarbank to Medan City. Postpaarbank is willing to lend a sum of 250,000 guilders with an interest rate of $6 \%$ to $8 \%$ for two years. ${ }^{20}$

Failing to borrow from Postpaarbank, Medan City transferred the loan plan to Nederlandsch-Indische Levensverzekerings en Lijfrente Maatschappij (Nillmij). Discussions were held between Medan City and Nillmij. Nillmij is willing to provide credit to Medan City with an interest of $7 \%$ for 20 years, but on condition that the city government must provide parcels or land parcels from the grant in Medan. Medan party agreed to the terms made by Nillmij. The agreement was signed on October 22, 1921 and approved by the Governor General Decree No. 31 July 1921 No.4. ${ }^{21}$ The money of 1,000,000 guilders was received by the city of Medan from Nillmij and 500,000 guilders were allocated for the planned public housing development. ${ }^{22}$

After the problem of funding needs was resolved, Medan City began working on their housing projects in the next few years. Several villages were chosen to be the places for the construction of this housing. Sekip Village, Djati Hulu Village, Padang Loemba Village, Sidodadi Village. Settlement improvements were also actually carried out by the Medan City Government apart from the names of the villages mentioned above, with the hope that Gemeente Kampongs or villages in the city of Medan could be better. ${ }^{23}$

\section{b. Rental price}

Volkshuisvesting is public housing aimed at the people, therefore the Medan City Government tried to make a price that was in accordance with the economic conditions of the community at that time. It is not the tenant ownership system that is applied, but the rental system. Residents can only rent at a rate set by the government. To adjust to the economic capacity of the community, several different types of housing were made with different rental rates. The allowable lease period is 50 years for European homes and 40 years for native houses. ${ }^{24}$

\footnotetext{
${ }^{19}$ Deo Widika Alamsyah, Waterleiding Maatschappij Ajer Beresih 1905-1942, Medan, Fakultas Ilmu Budaya USU, 2019, p 81-82

${ }^{20}$ Verslag Betreffende De Gemeente Medan Over Het Jaar 1921, Medan, Varekamp \& Co, 1922, p 30

${ }^{21}$ Ibid., p 31

${ }^{22}$ Ibid., p 89

${ }^{23}$ Verslag Betreffende De Gemeente Medan Over Het Jaar 1922, Medan, Varekamp \& Co, 1923, p 7 ., "Pada laporan tahunan Gemeente Medan tahun 1922 disebutkan bahwa Pemerintah Gemeente Medan Juga sedang menupayakan perbaikan di wilayah Sei Kerah".

${ }^{24}$ De volkshuisvesting Te Medan., 1925
} 
Table 2. Determined Rental Prices

\begin{tabular}{|c|c|}
\hline House type & Monthly Rental Prices \\
\hline A & 80 Gulden \\
\hline B & 85 Gulden \\
\hline D & 45 Gulden \\
\hline H & 75 Gulden \\
\hline K & 60 Gulden \\
\hline L & 57.50 Gulden \\
\hline N & 14 Gulden \\
\hline O & 9 Gulden \\
\hline P & 6.50 Gulden \\
\hline Q & 6.50 Gulden \\
\hline R & 5.50 Gulden \\
\hline Store & 30 Gulden \\
\hline So & 85 Gulden \\
\hline
\end{tabular}

Source: Volkshuisvesting te Medan, 1925

The rental price in table 2 is actually a higher than estimated price calculated from all the needs for housing itself. The initial calculation made by the Medan City Employment Office is purely for social purposes by calculating the actual rental price. Meanwhile, the price set by the city council is more expensive than what the Medan City Employment Service calculates. ${ }^{25}$ Freek Colombijn stated that the price of 5.50 guilders for the lowest type of house was a price which was also considered too expensive for the people with the lowest income. ${ }^{26}$ Even though they are at risk of being too profitable, what the council does can also be interpreted as an effort to increase the finances of Medan City. As previously explained, that housing funding comes from debt so that they may think that the reason for taking more profits is correct.

Homes with low rental prices usually have minimal facilities such as no bathroom. Therefore, the Medan City Government made public baths for the lowest type of house because the water supply was obtained free of charge from a private water company in Medan at that time, namely N.v. Waterleiding Maatschappij Ajer Clean up. What the Medan government does can be interpreted as an effort to lighten the community with the lowest economic capacity so that they no longer need to think about spending to pay for water.

\subsection{Establishing Public Housing in Kampung Kota}

It should be noted, Medan was originally a village area with the name Medan Putri. No wonder why until the formation of Gemeente Medan, there are still many villages within the Gemeente Medan area. With the condition that the density in the center of Medan or the Kesawan area and its surroundings is no longer representative for housing construction, then this housing development must be carried out in a village or on the outskirts of the city, especially in these villages that many slum housing is found as previously explained. Another aim of this was that at that time the urban government was also working on improving the village. Later, the names of the existing houses will be named after the village where the housing is built. An interesting example is the housing complex of Kampung Sidodadi. The

\footnotetext{
${ }^{25}$ De Volkshuisvesting te Medan ., 1925

${ }^{26}$ Freek, Op., Cit, p 439
} 
term Sidodadi itself is actually not the original term of the original people in Deli, namely Malay, but a Javanese term which means "has become". The use of this name was given by the city government to attract potential residents to be interested in owning a nice house. Perhaps the use of the term sidodadi was to attract Javanese people who were in Medan at that time. ${ }^{27}$

Kampung Sekip is the first project of public housing development in Medan. Starting with the pilot houses in Sekip village, namely 4 permanent houses and 17 semi-permanent houses. For permanent houses, there are 1 room measuring $4 \times 4$ meters and 2 rooms measuring $4.5 \times 5.5$ and equipped with a kitchen, bathroom and toilet. For semi-permanent houses built with 3 rooms. With the complete terrace of the house, and 2 rooms. Correspond stone. This house is designed using wooden poles and walls and woven bamboo booths. Then for semi-permanent houses it was added to 38 units. ${ }^{28}$ Medan City plans to build several houses outside Kampung Sekip, namely Petisah and Polonia Baru. It is planned that 45 permanent houses and 185 semi-permanent houses will be built in Kampung Petisah and the required money is estimated at 500,000 guilders. There was a request from the housing association "Toba" to the Medan City Government to pay attention to them by asking them to build 40 houses in Polonia and give them the right to rent. Due to the absence of funds available that year, the housing development projects in Polonia and Petisah were canceled. ${ }^{29}$

After receiving funds for the implementation of this housing development, several village places began to be seen to be used as construction sites after Kampung Sekip. Several villages were selected, such as Djati Oeloe, Padang Loemba and Sidodadi. The most basic reason why these villages were chosen was because the land there belonged to the government. In addition, if we look at the Gemeente Medan map in Figure 1, it shows the position of each selected village, namely Sidodadi Village in the North, Padang Loemba Village in the East, Djati Oeloe Village in the South and Sekip Village in the West, then some from this village is in the corner of the city. So when interpreted, it seems that the Medan City Government is indeed focused on building housing on all four sides of its area and reaching corner areas that are far from the city center so that it can revive existing suburban areas.

\footnotetext{
${ }^{27}$ De Volkshuisvesting te Medan ., 1925

${ }^{28}$ ibid

${ }^{29}$ Verslag Betreffende De Gemeente Medan Over Het Jaar 1922, Op., Cit , p 213
} 


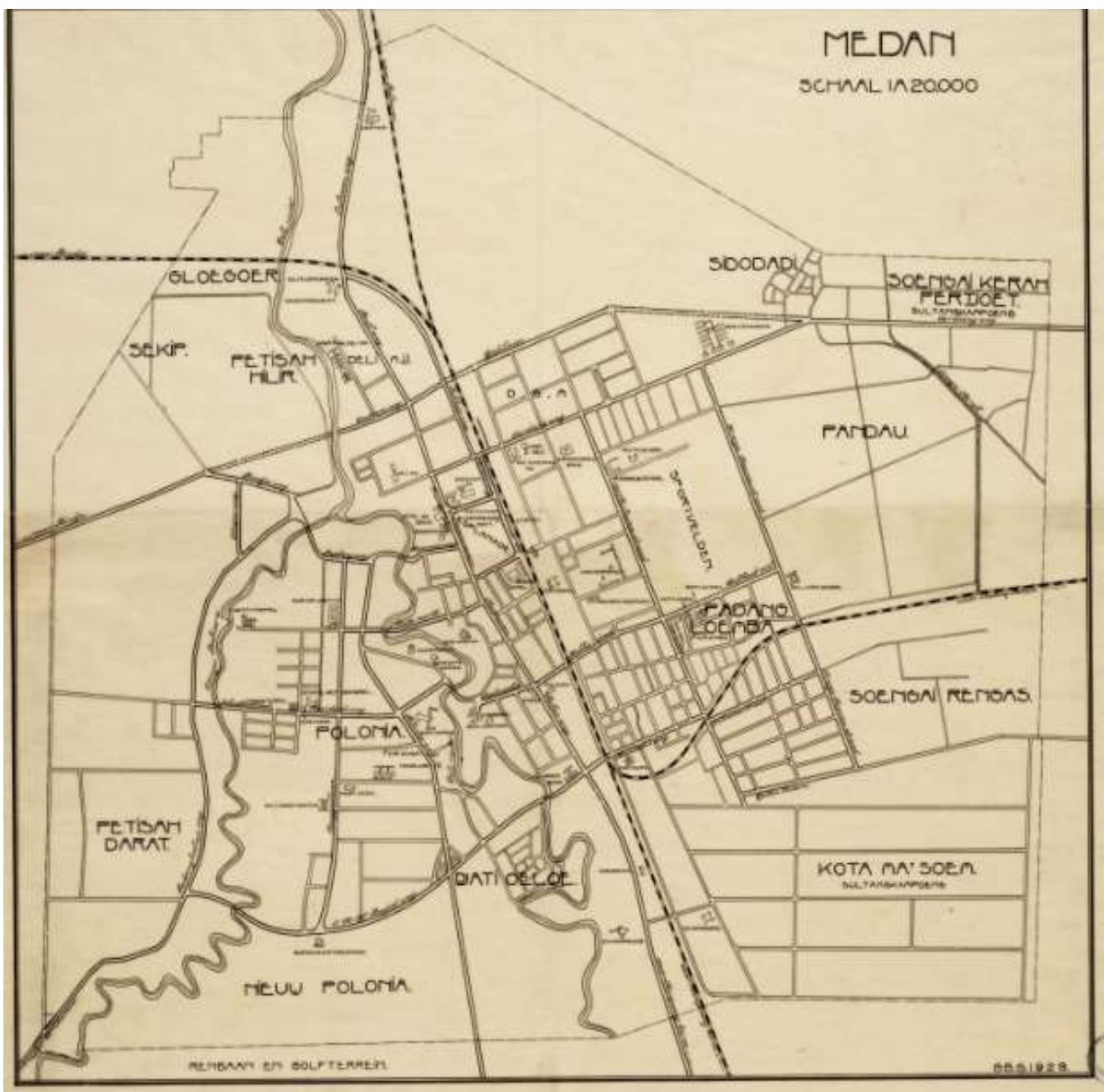

Figure 1. Map of Gemeente Medan 1928

Source: Gemeente Bureau Grondzaken., http://colonialarchitecture.eu/obj?sq=id\%3Auuid\%3A091eb022-fc82-4d38-958af9c20c5c73fa

For Kampung Djati Oeloe, the work was carried out after the City Council's decision on 4 August 1921 stated that the work could be carried out. A total of 220,570 guilders was budgeted with a target of building 30 houses of various types. ${ }^{30}$

The next location is Kampung Padang Loemba. The 1923 budget set out to build housing there. By the decision of the City Council dated August 15, 1923, No. 150, it is targeted that 48 houses will be built. In order to be able to build housing in that location, the

${ }^{30}$ De Volkshuisvesting Te Medan, 1925 
Medan City Government had to relocate several residents to move from there. The City gave them a new location to occupy the northern side of Serdang Street. ${ }^{31}$ Housing work in Sidodadi Village has been carried out in two stages since 1923 and completed in 1925. In the second phase, it is planned that 40 houses can be built thereafter.

\section{a. Public Housing Development in Medan}

If you look at table 3, up to 1929 there were 417 houses with various types, and even new types of houses appeared. Of the 417 houses, about 1997 people live there, and if you present each house, 4.79 people live there. Of course this shows the good development of public housing in Medan at that time. Even housing work is also carried out outside of the villages previously mentioned. The success of the construction of public housing for the people also opened new things, namely houses at a lower price than before at 3.30 guilders in Kampong Sekip and Djati Oeloe in 1938. ${ }^{32}$

Another thing that shows the impact of this public housing development is that the housing business in Medan has good prospects which also resulted in the birth of a housing company, namely N.v Medansche Woningvoorziening. Although only working on a limited number of housing and houses for Ambtenaars in Medan at that time, the existence of this housing company indicates that housing development in Medan is in the right direction. ${ }^{33}$

Table 3. Number and Type of Houses until 1928

\begin{tabular}{|c|c|c|c|}
\hline Village & House type & Number of Houses & Monthly Rent \\
\hline \multirow[t]{7}{*}{ Sekip } & Toko & 1 & 25 Gulden \\
\hline & $\mathrm{D}$ & 4 & 35 Gulden \\
\hline & $\mathrm{E}$ & 2 & 12 Gulden \\
\hline & $\mathrm{F}$ & 6 & 7,50 Gulden \\
\hline & $\mathrm{G}$ & 28 & 5,50 Gulden \\
\hline & $\mathrm{F}$ & 8 & 6.50 Gulden \\
\hline & Total & 49 & - \\
\hline \multirow[t]{11}{*}{ Djati Oeloe } & Toko & 2 & 45 Gulden \\
\hline & $\mathrm{A}$ & 4 & 80 Gulden \\
\hline & $\mathrm{B}$ & 5 & 85 Gulden \\
\hline & $\mathrm{D}$ & 8 & 45 Gulden \\
\hline & $\mathrm{H}$ & 2 & 75 Gulden \\
\hline & $\mathrm{K}$ & 7 & 60 Gulden \\
\hline & $\mathrm{L}$ & 4 & 57,50 Gulden \\
\hline & $\mathrm{M}$ & 20 & 14 Gulden \\
\hline & $\mathrm{N}$ & 40 & 9 Gulden \\
\hline & $\mathrm{O}$ & 98 & 6.50 Gulden \\
\hline & Total & 190 & - \\
\hline \multirow{4}{*}{$\begin{array}{c}\text { Padang } \\
\text { Loemba I }\end{array}$} & $\mathrm{Ma}$ & 18 & 17 Gulden \\
\hline & $\mathrm{Oa}$ & 14 & 7,50 Gulden \\
\hline & $P$ & 8 & 6,50 Gulden \\
\hline & $\mathrm{Q}$ & 8 & 5,50 Gulden \\
\hline
\end{tabular}




\begin{tabular}{|c|c|c|c|}
\hline & Total & 48 & - \\
\hline \multirow[t]{5}{*}{ Sidodadi } & $\mathrm{Ma}$ & 6 & 15 Gulden \\
\hline & $\mathrm{Oa}$ & 8 & 8 Gulden \\
\hline & $\mathrm{Q}$ & 24 & 6 Gulden \\
\hline & $\mathrm{R}$ & 2 & 30 Gulden \\
\hline & Total & 40 & - \\
\hline \multirow{7}{*}{$\begin{array}{c}\text { Padang } \\
\text { Loemba II }\end{array}$} & $\mathrm{Ma}$ & 14 & 17.50 Gulden \\
\hline & $\mathrm{Oa}$ & 10 & 7,50 Gulden \\
\hline & $\mathrm{P}$ & 10 & 6,50 Gulden \\
\hline & Q & 10 & 5,50 Gulden \\
\hline & $\mathrm{Re}$ & 2 & 32,50 Gulden \\
\hline & $\mathrm{S}$ & 6 & 25,50 Gulden \\
\hline & Total & 52 & - \\
\hline \multirow{4}{*}{$\begin{array}{l}12 \text { Rumah } \\
1927\end{array}$} & $\mathrm{~T}$ & 3 & 85 Gulden \\
\hline & $\mathrm{I}$ & 5 & 70 Gulden \\
\hline & $\mathrm{V}$ & 4 & 55 Gulden \\
\hline & Total & 12 & - \\
\hline \multirow{7}{*}{$\begin{array}{c}26 \text { Rumah } \\
1928\end{array}$} & $\mathrm{Mb}$ & 6 & 25 Gulden \\
\hline & $\mathrm{Rb}$ & 4 & 40 Gulden \\
\hline & $\mathrm{U}$ & 4 & 75 Gulden \\
\hline & $\mathrm{V}$ & 4 & 60 Gulden \\
\hline & $\mathrm{W}$ & 8 & 20 Gulden \\
\hline & Total & 26 & - \\
\hline & Total & 417 & - \\
\hline
\end{tabular}

Source: Verslag Betreffende De Gemeente Medan Over Het Jaar 1929, Medan, Varekamp \& Co, 1930

\section{Conclusion}

This public housing policy aimed at people with low economies like this was really needed by the people of Medan at that time. That the increasing population, the difficult economic situation of the community and the frequent granting of land have led to the establishment of slum houses in Medan. With limited circumstances and capabilities, Medan City can slowly improve its slum housing areas, especially in the village area. as for what the Medan City Government has shown is a sufficient solution to help the lives of its people. With the number of public housing that continues to grow every year, it shows that the cheap houses they build are really needed at that time.

\section{Acknowledgment}

This article couldn't be published without financial support from "Penelitian TALENTA USU skema Penelitian Dasar" with contract number 4142 / UN5.1.R / PPM / 2020 on April 27, 2020. Thanks to Lembaga Penelitan USU for accommodating this research. In addition, we also thanks to Arsip Nasional Republik Indonesia and Perpustakaan Nasional Republik Indonesia because many references to this article can be found there. 


\section{References}

Alamsyah, Deo Widika., 2019, Waterleiding Maatschappij Ajer Beresih 1905-1942, Medan, Fakultas Ilmu Budaya USU.

Colombijn, Freek., 2011., Public Housing in Post-Colonial Indonesia The Revolution Of Rising Expectations, Bijdragen Tot de Taal- Land- en Volkenkunde/ Juornal Of Humanities and Sosial Sciences Of Southeast Asia and Oceania.

De Volkshuisvesting te Medan, 1925

De Sumatra Post, 28 oktober 1924

De Sumatra Post., 19 Mei 1928

De Sumatra Post., 24 Januari 1939

Flieringa, G., 1930. De Zorg Voor DE Vokshuisvesting In De Stadgemeenten . N Nederlandsch Oost Indie In Het Bijzonder In Semarang., Grevenhage Martinus Nijhoff. Jansen, Gerad.,1925., Grantrechten In Deli., Medan, Oostkust Van Sumatra Instituut.

Kastelijn, J.S.C., 1911, Deli Planters Vereeniging. Handelingen Van Het Ie Congres 1911. Het verkrijgen van een inheemsche Aïteiders-bevolking, Medan ,TYP J Halerman.

Koloniale verslag 1915

Nasution, Junaidi., 2018., Transformasi Moderenitas di Kota Medan : Dari Kampung Medan Putri Hingga Gemeente Medan, Jurnal Masyarakat Sejarawan Indonesia.

Said, Mohhamad., 1977 Koeli Kontrak Tempoe Doeloe. Dengan Derita dan Kemarahannya, Medan, Waspada

Suprayitno, et al. (2020). From Labuhan Deli to Belawan: The Removal of Harbor in

Medan during the Dutch Colonial Period of 1863-1942. Budapest International Research and Critics Institute-Journal (BIRCI-Journal). P. 1392-1402

Tideman., 1919., Penampungan Kuli Kontrak di Panatai Timur Sumatera, Colonial Student.

Tillema, H.F., 1926., Zonder Tropen-geen Europam, Bloemendal,

Verslag Betreffende De Gemeente Medan Over Het Jaar 1919, 1920., Medan, Varekamp \& Co.

Verslag Betreffende De Gemeente Medan Over Het Jaar 1920, 1921., Medan, Varekamp \& Co.

Verslag Betreffende De Gemeente Medan Over Het Jaar 1921., 1922 Medan, Varekamp \& Co.

Verslag Betreffende De Gemeente Medan Over Het Jaar 1922., 1923, Medan,Varekamp \& Co.

Verslag Betreffende De Gemeente Medan Over Het Jaar 1923., 1924., Medan, Varekamp \& Co.

Verslag Betreffende De Gemeente Medan Over Het Jaar 1929., 1930, Medan, Varekamp \& Co. 